\title{
The Perception of Students in Using ICT in ESP Course at the Faculty of Mathematics and Science of Universitas Negeri Padang
}

\author{
Darliza Listari $^{1^{*}}$ and Yenni Rozimela ${ }^{2}$ \\ ${ }^{12}$ English Department, FBS Universitas Negeri Padang, Padang, Sumatera Barat 25131, Indonesia \\ *Corresponding author. Email: darlizalistari96@gmail.com
}

\begin{abstract}
Information Communication and Technology (ICT) is a form of technology used for creating, displaying, storing, manipulating, and exchanging information to support teaching and learning activities. Since 2017, Universitas Negeri Padang using ICT as a teaching and learning media to improve the quality of teaching and learning activity. Unfortunately, studies about evaluation of user acceptance on using ICT in teaching and learning activity, very specifically ESP course, are still under-researched. Related to this issue, this present research has aim to describe the using ICT in ESP course at Faculty of Mathematics and Science of Universitas Negeri Padang, based on the perceptions of students. This is a qualitative research that describe students' perceptions on using ICT in ESP Course. The subject of this research were the students of Faculty of Mathematics and Science that taken the ESP course in 2020/2021 academic year. The data were collected through a closed-ended questionnaire based on the Technology Acceptance Model (TAM). The findings reveal that a large majority of students have positive perceptions on using ICT in ESP courses as well as for their future careers.
\end{abstract}

\section{Keywords: Perceptions, ICT, ESP Course}

\section{INTRODUCTION}

In the $21^{\text {st }}$ century, Information Communication and Technology (ICT) have a significant impact on many aspects of life. ICTs are being used by people from all sectors, particularly in education. According to UNESCO, ICT is defined as a kind of device that are being used to create, display, store, manipulate, and exchange information [1]. ICT is recognized in education as a part of useful tool in teaching and learning processes in the classroom to stimulate students to learn actively [2]. as a result, ICT is now widely used in schools, colleges, and universities.

In Indonesia, the 2013 curriculum incorporates ICT as a learning concept to encourage students' learning autonomy and communicative development. Integrating ICT into studies can boost students' motivation to learn and increase their interest in the subject. Since 2017, Universitas Negeri Padang (UNP) has also integrated ICT into the teaching and learning process. ICT has familiarized to students, such as projectors, laptops, computers, and the internet. It uses as a helpful learning tool to encourage students' independence and autonomous learning.

Furthermore, during the Covid-19 pandemic, teaching and learning activity at UNP has moved to online learning. The students can use ICT as an online learning platform, for example, using Learning Management System (LMS) or e-learning, Zoom Cloud Meeting, YouTube, WhatsApp, and others during the virtual teaching and learning process to keep the communication between students and lecturers. It allows students to learn more effectively by utilizing ICT to find learning resources and assisting students in learning the language and acquiring knowledge.

ICT is also more commonly used in language learning and teaching. In English language learning, ICT as learning media has benefits to address the needs of students and make them active learning[3]. Kinds of media in ICT are used often in English language teachings, such as the Overhead Projector, Audio, Web, Video, Word processing software, software for presentation, and the World Wide Web [4].

There have been many researchers conducted studies about using ICT tools in ESP, for example, using Course/Learning Management Systems, Corpora, Wikis [5]; Edmodo [6]; Zoom [7]; E-dictionary [8]; Kahoot [9]. In short, based on the current previous studies, many different technologies, ranging from traditional to online platforms, are successfully used in ESP courses to enhance the teaching and learning development. 
In learning English for specific purposes, the adoption of ICT in ESP brings students with approaches to master languages for different reasons[5]. the benefit of ICT in ESP is to provide some opportunities for interaction in the learning process, informative actions representative of specific specialist or academic settings, and collaborative learning [10]. It is in line with [11] stated ICT allows for a higher quality lesson through collaboration. Furthermore, using ICT in ESP courses enables learners to interact and engage in real communication in their professional discourage group; obtain knowledge relevant to their career; and publish their thoughts, all of which can provide earners with a sense of empowerment [12]. Thus, to improve the quality of the ESP program, the teacher and students should work collaboratively.

However, as a teaching and learning tool in educational systems, ICT emerged as an innovation perceived as new by an individual or other unit of adoption. Many factors contribute to whether an individual develops favorable or unfavorable attitudes toward the revolution, and consequently either adopts or rejects them. The adoption of ICT in the educational process implies that ICT benefits both lecturers and students [8][13][14]. However, but also ICT harms students, and teachers may become fixated on the technological component rather than the subject matter [15], the difficulty in classroom control [16], and students get a short span of attention [17]. thus, perception is essentially important necessary for educational innovation, effectiveness, implementation, and action. So far as how students' perception of using ICT in ESP teaching and learning is concerned, whether they are ready to accept ICT in their teaching and learning activity or not.

Thus, when ICT is introduced at Universitas Negeri Padang, particularly in ESP courses at the Faculty of Mathematics and Science, both positive and negative ICT possibilities appear. It is necessary to discuss the use of ICT in ESP courses. We need to know how the use of ICT affects the ESP teaching and learning process. The outcome of this discussion may aid in determining how to address the challenges. It is also to help solving the problems or challenges faced by individuals and institutions when integrating ICT into teaching and learning activities[18].

From this point, the need for this research has come out. The perception toward ICT plays a huge role in its implementation in teaching and learning, and it should be investigating within this context of this research to improve how to using ICT in a better way. In sum up, it needs to know the perception of using ICT in the ESP courses faced by students.

Based on the explanation above, this research seeks to investigate students' perceptions to see the use of ICT in the ESP context, especially using ICT in the ESP course at Universitas Negeri Padang. In short, this research investigated the students' perceptions on using ICT in ESP courses at Faculty of Mathematics and Sciences of Universitas Negeri Padang.

\section{METHODS}

This study is qualitative research. Qualitative research involves the gathering, analysis, and interpretation of extensive narrative and visual data to acquire insights into a specific phenomenon of interest [19]. Thus, it describes students' perceptions on using ICT in ESP courses.

Participants in this study were students who had taken ESP course in academic year 2020/2021 at Faculty of Mathematics and Science of Universitas Negeri Padang. There were 542 students. In order to make the data analysis organize well, the number of respondent was limited based on the criteria [20]. He stated that if the population is less than 100 , all of them are taken as the sample. If the population is more than 100, there are at least $10 \%$ of the population is chosen as the sample. Therefore, the researcher took $10 \%$ of the population as the respondent in this research. Thus, the total respondent in this research were 55 students.

The data was collected from the closed-ended questionnaire that distributed by using Google Form. The questionnaires consisted of 47 items and 3 demographics information items. Respondents were instructed to select one of five alternatives to answer the closed-ended questions: Strongly Agree (SA), Agree (A), Neutral (N), Disagree (D), and Strongly Disagree (SD). the different choices from Strongly Agree to Strongly Disagree correspond to numerical values ranging from 5 to 1 .

The questionnaire used some indicators based on the Technology Acceptance Model (TAM) theory as a guideline in giving the questionnaire to the students. TAM is a behavioral concept theory that is widely used to study the process of information technology adoption that was proposed by Davis in 1989. TAM provides a foundation for determining the impact of external factors on its users' beliefs, attitudes, and goals. The TAM model and its indicators have been validated in order to assess technology acceptance. As a result, regardless of whether users accept it, the use of TAM can explain the use of ICT in ESP classrooms.

According to theory of Davis in 1989, the perception of individuals to adopt technologies is based on five indicators, namely [21]:

1. Perceived Usefulness (PU), describe a person's belief that using the system will improve performance.

2. Perceived Ease of Use (PEU), describes how certain people are that using an information system is a simple task that does not require the user to struggle.

3. Attitude Toward Using (ATU), the proclivity to respond to pleasant or unpleasant conditions on a specific object at first.

4. Behavioral Intention to Use (BI), defined as a person's desire to perform a specific behavior or a person's proclivity to continue using a specific technology.

5. Actual Usage (A), defined as a person's performance of a specific behavior 
The perception indicators for ICT use are shown in Table 1. From these indicators, the researcher analyzed students' perceptions on using ICT in ESP course based on the answers given to each indicator.

Table 1. Indicators for questionnaire

\begin{tabular}{|c|c|}
\hline \multirow{4}{*}{ Indicators } & Sub Indicators \\
\hline \multirow{4}{*}{ Perceived Usefulness } & Work more quickly \\
\cline { 2 - 2 } & Improve job performance \\
\cline { 2 - 2 } & Increase productivity \\
\cline { 2 - 2 } & Effectiveness \\
\cline { 2 - 2 } & Make job easier \\
\hline \multirow{4}{*}{ Perceive of Ease of Use } & Useful \\
\cline { 2 - 2 } & Easy to learn \\
\cline { 2 - 2 } & Controllable \\
\cline { 2 - 2 } & Elear and understandable \\
\cline { 2 - 2 } & Flexible \\
\hline \multirow{2}{*}{ Attitude toward use } & Easy to use \\
\cline { 2 - 2 } Behavioral Intention & Accept \\
\hline \multirow{2}{*}{ Actual Usage } & Ignore \\
\hline Source: Factor analysis of & Motivate to use \\
\hline \multirow{4}{*}{ TA items by Davis (1989) }
\end{tabular}

The researcher discussed the findings in questionnaire by calculating the number of respondent and the data received. The researcher counted the average of all students responses and their total scores. Then the researcher was able to describe the students' perceptions in using ICT in ESP course. To infer data, the researcher explained whether such perceptions are positive or negative.

\section{FINDINGS AND DISCUSSION}

The findings were obtained from the result of an analysis of the answers given by each participant. The answers represent each indicator of using ICT in ESP course based on TAM. For the research findings and discussion discussed below.

Perceived of Usefulness (PU)

Perceived of usefulness (PU) in this study refers to the extent to which students feel that utilizing ICT in an ESP course would improve the efficiency of their work or performance. There were 11 statements designed to elicit students' attitudes regarding the usage of ICT in the ESP course. The questionnaire results are shown in the table below:

Table 2. Students' perception on using ICT in ESP Course based on Perceived Usefulness

\begin{tabular}{|c|c|c|c|c|c|c|}
\hline \multirow{2}{*}{ No Items } & \multicolumn{5}{|c|}{ Students' Response } & \multirow{2}{*}{ Total } \\
\cline { 2 - 6 } & SD & D & N & A & SA & \\
\hline 1 & - & 4 & 5 & 32 & 14 & 55 \\
\hline 2 & - & 5 & 4 & 33 & 13 & 55 \\
\hline 3 & - & - & 5 & 41 & 9 & 55 \\
\hline 4 & - & 5 & 9 & 26 & 15 & 55 \\
\hline 5 & - & - & 15 & 31 & 9 & 55 \\
\hline 6 & - & 1 & 14 & 32 & 9 & 55 \\
\hline 7 & - & - & 11 & 34 & 9 & 55 \\
\hline 8 & - & - & 3 & 35 & 17 & 55 \\
\hline 9 & - & - & 10 & 34 & 11 & 55 \\
\hline 10 & - & - & 8 & 31 & 6 & 55 \\
\hline 11 & - & - & 2 & 37 & 16 & 55 \\
\hline 12 & - & - & 6 & 36 & 13 & 55 \\
\hline Total & 0 & 15 & 92 & 402 & 141 & \\
\hline Percentage & $0 \%$ & $2 \%$ & $14 \%$ & $62 \%$ & $22 \%$ & $100 \%$ \\
\hline
\end{tabular}

As shown in table 2, it is apparent that not all students believe that ICT was useful to their success in the ESP course. From a total of 55 students, $84 \%(62 \%$ $=\mathrm{A}, 22 \%=\mathrm{SA})$ thought that ICT might improve their performance in the ESP course. \% of students felt that
ICT will not help their performance. The remaining students (14\%) were neutral.

On the basis of the foregoing data, students feel that it is simple to learn English using ICT in ESP courses. Students also utilize ICT to enhance the 
opportunities for ESP courses to receive information to enable them to perform tasks swiftly. This claim is aligned with Vitoria, L et al [22] who found that students see ICT as a useful tool for grasping the topic because various sources can be accessed online at their convenience. In addition, students thought that digital platforms are extremely effective instruments for learning since they include characteristics such as audio and video on ICT gadgets so that they had authentic learning. Moreover, students may rapidly obtain study materials and post homework using ICT.

Overall, virtually all students believed that the use of ICT in ESP courses was helpful in the first indicator.
They felt that ICT was increasing in the ESP course and played an essential part in the English language learning process as a learning media. It described the students' perceptions of usefulness as positive.

Perceived of Ease of Use (PEU)

In this study, perceived ease of use refers to the degree to which students think that studying through ICT in an ESP course is free of effort and straightforward. There were 9 statements designed to elicit students' impressions about the ease of use of ICT in the ESP course. The questionnaire results are shown in the table below:

Table 3. Students' perception on using ICT in ESP Course based on Perceived of Ease of Use

\begin{tabular}{|c|c|c|c|c|c|c|}
\hline \multirow{2}{*}{$\begin{array}{c}\text { Total of } \\
\text { Items }\end{array}$} & \multicolumn{5}{|c|}{ Students' Response } & \multirow{2}{*}{ Total } \\
\cline { 2 - 6 } & SD & D & N & A & SA & \\
\hline 13 & - & 1 & 8 & 41 & 5 & 55 \\
\hline 14 & - & - & 9 & 39 & 8 & 55 \\
\hline 15 & - & - & 10 & 31 & 14 & 55 \\
\hline 16 & - & - & 17 & 32 & 6 & 55 \\
\hline 17 & - & - & 4 & 47 & 4 & 55 \\
\hline 18 & - & - & 9 & 43 & 3 & 55 \\
\hline 19 & 4 & 1 & 5 & 35 & 10 & 55 \\
\hline 20 & - & - & 11 & 40 & 4 & 55 \\
\hline Total & 4 & 2 & 73 & 298 & 54 & \\
\hline percentage & $1 \%$ & $0 \%$ & $17 \%$ & $69 \%$ & $13 \%$ & $100 \%$ \\
\hline
\end{tabular}

As depicted in table 3 , it is clear that not all of students perceive that ICT is easy to use. From 55 students, there were $82 \%(69 \%=\mathrm{A}, 13 \%=\mathrm{SA})$ students believe that using ICT in ESP course was easy to learn, and $1 \%$ of students thought that ICT was difficult to operate. The rest of students $(17 \%)$ were neutral.

Based on the findings, the student thought that utilizing ICT in the ESP Course did not cause them difficulty, even as a new user. Because students and lecturers nowadays have a natural passion towards technology. As a result, when ICT was presented in an ESP classroom activity, the students found it easy to learn how to use it.

Furthermore, employing ICT tools in an ESP course during virtual teaching and learning makes it easier for students to attend the class. They should minimize face-to-face meetings and instead enroll in an online class. They only required the Zoom link given by the lecturer or to sign in to e-learning2unp.ac.id and directly attend the class using a browser on their mobile phone or computer/laptop. It is similar with Hariadi and Simanjuntak's [23] result that students utilized their smartphones to participate in English asynchronous elearning since it was simple to use and the program was easily accessible through it. Thus, it described that the software program or online platforms used in the ESP course, such as e-learning2unp.ac.id and Zoom, were great effort and free from difficulty.

Moreover, students found it easy to use ICT in ESP class since the university launched a blended learning program (combining traditional face-to-face teaching and learning with e-learning technology) just before the Covid-19 outbreak.

Overall, the second indicator reveals that almost all students thought that utilizing ICT in the ESP Course was easy. They thought that utilizing ICT in an ESP course was flexible and did not put them at a disadvantage. Students and lecturers are more inclined to accept applications that are regarded to be easy to use than others. It described that the perceptions of students regarding ease of use were positive.

Attitude towards Usage (ATU)

In this study, attitude toward usage refers to the extent to which students evaluate their thoughts (positive or negative) when doing a specific behavior. There were 9 statements used to elicit students' attitudes toward the use of ICT in the ESP course. The questionnaire results are shown in the table below: 
Table 4. Students' perception on using ICT in ESP Course based on Attitude toward Use

\begin{tabular}{|c|c|c|c|c|c|c|}
\hline $\begin{array}{c}\text { Total of } \\
\text { Items }\end{array}$ & \multicolumn{5}{|c|}{ Students' Response } & \multirow{2}{*}{ Total } \\
\cline { 2 - 6 } SD & D & N & A & SA & \\
\hline 21 & - & - & 7 & 39 & 9 & 55 \\
\hline 22 & - & - & 7 & 33 & 15 & 55 \\
\hline 23 & - & - & 5 & 35 & 15 & 55 \\
\hline 24 & - & - & 6 & 36 & 13 & 55 \\
\hline 25 & - & - & 2 & 30 & 23 & 55 \\
\hline 26 & - & - & 11 & 38 & 6 & 55 \\
\hline 27 & - & - & 11 & 31 & 13 & 55 \\
\hline 28 & - & 15 & 7 & 33 & - & 55 \\
\hline 29 & - & 13 & 23 & 19 & - & 55 \\
\hline Total & 0 & 28 & 79 & 264 & 94 & \\
\hline Percentage & $0 \%$ & $6 \%$ & $17 \%$ & $57 \%$ & $20 \%$ & $100 \%$ \\
\hline
\end{tabular}

As presented in table $4,77 \%$ of students had a good attitude toward the use of ICT in the ESP course, whereas $17 \%$ had no ideas about ICT and $6 \%$ had a negative perspective. Using ICT in ESP classes was an exciting method to study English, especially during virtual learning because to the Covid-19 outbreak, thus they preferred using ICT when they had ESP class. It is lined with Cakrawati [24], reading online resources using learning platforms may be a very fascinating experience for students.

Thus, employing ICT in an ESP course will encourage students to intend and accept the use of ICT in teaching and learning activities, particularly communication, which is critical during virtual teaching and learning. As a result, they would be inclined to employ it in their activities as well. However, while employing ICT in the ESP course, such as internet connection, there was a difficulty because not all students had a reliable network. It is related with Laili and Nashir's [7] finding that an unstable connection causes interrupted voice while the lecturer presents the subject, causing the points of the lesson to be communicated to students imperfectly. As a result, having a strong internet connection will provide a better experience during remote learning utilizing ICT tools.

To summarize, the third indicator reveals that almost all students indicated that they had a good attitude regarding the use of ICT in the ESP course. It said that students' perceptions were positive based on their attitudes toward usage.

Behavioral Intention (BI)

In this study, behavioral intention refers to the degree to which pupils intend to utilize technology. It determined the desire to employ ICT in the ESP course. There were 11 statements used to elicit students' opinions of ICT use in the ESP course based on behavioral intention. The questionnaire results are shown in the table below:

Table 5 .Students' perception on using ICT in ESP Course based on Behavioral Intention

\begin{tabular}{|c|c|c|c|c|c|c|}
\hline \multirow{2}{*}{$\begin{array}{l}\text { Total of } \\
\text { Items }\end{array}$} & \multicolumn{5}{|c|}{ Students' Response } & \multirow{2}{*}{ Total } \\
\hline & SD & D & $\mathbf{N}$ & A & $\mathbf{S A}$ & \\
\hline 30 & - & - & 3 & 39 & 13 & 55 \\
\hline 31 & - & - & 4 & 42 & 9 & 55 \\
\hline 32 & - & - & 3 & 43 & 9 & 55 \\
\hline 33 & - & - & 4 & 42 & 9 & 55 \\
\hline 34 & - & - & 4 & 42 & 9 & 55 \\
\hline 35 & - & - & 8 & 38 & 9 & 55 \\
\hline 36 & - & - & 4 & 38 & 13 & 55 \\
\hline 37 & - & - & 10 & 32 & 13 & 55 \\
\hline 38 & - & - & 21 & 21 & 13 & 55 \\
\hline 39 & - & 5 & 12 & 25 & 13 & 55 \\
\hline 40 & - & 4 & 10 & 28 & 13 & 55 \\
\hline Total & 0 & 9 & 83 & 390 & 123 & \\
\hline Percentage & & $2 \%$ & $14 \%$ & $64 \%$ & $20 \%$ & $100 \%$ \\
\hline
\end{tabular}

Table 5 showed the result that there were $84 \%$ students motivated to use ICT in ESP course, and there was $2 \%$ student unmotivated in using ICT in ESP course. The rest of students (14\%) were neutral. They believed that features of ICT tools was useful and helped them to learn English. Thus, they would continue to use ICT in the future. It is line with Basri \& Paramma
[25] finding that almost all students planned to use ICTbased learning in the future. ICT can be feasible application to be recommended in supporting learning classroom in the future. This means that ICT is believed to be valuable learning tool to enhance quality education, especially in learning English for specific purpose. 
Overall, students' intentions were influenced by their attitudes toward ICT. As a result, students' perceptions of the utility and simplicity of use influenced users' intentions to utilize ICT (Davis et al in Wiyaka, et al. 2019) [26]. To summarize, the fourth indicator that almost all students strongly agreed that utilizing ICT in the ESP course inspired them to continue using it and motivated others to use it. They thought that utilizing ICT in an English language learning program encouraged students to use ICT whenever they wanted. It stated that students' perceptions based on behavioral intention were positive.

\section{Actual Use (AU)}

In this study, actual use refers to the extent to which pupils use technology. There were 7 statements designed to elicit students' perspectives based on their actual use of ICT in the ESP course. The questionnaire results are shown in the table below:

Table 6. Students' perception on using ICT in ESP Course based on Actual Use

\begin{tabular}{|c|c|c|c|c|c|c|}
\hline \multirow{2}{*}{$\begin{array}{c}\text { Total of } \\
\text { Items }\end{array}$} & \multicolumn{5}{|c|}{ Students' Response } & \multirow{2}{*}{ Total } \\
\hline & SD & D & $\mathbf{N}$ & $\mathbf{A}$ & SA & \\
\hline 41 & - & 3 & 15 & 37 & - & 55 \\
\hline 42 & - & 5 & 9 & 32 & 9 & 55 \\
\hline 43 & - & 9 & 8 & 29 & 9 & 55 \\
\hline 44 & 9 & 9 & 11 & 22 & 4 & 55 \\
\hline 45 & - & 8 & 7 & 23 & 17 & 55 \\
\hline 46 & - & 4 & 21 & 19 & 2 & 55 \\
\hline 47 & 9 & 4 & 5 & 46 & - & 55 \\
\hline Total & 18 & 42 & 76 & 208 & 41 & \\
\hline Percentage & $5 \%$ & $11 \%$ & $20 \%$ & $54 \%$ & $10 \%$ & $100 \%$ \\
\hline
\end{tabular}

The results in table 6 showed that $10 \%$ of students highly agreed, $55 \%$ agreed, $20 \%$ were neutral, and $11 \%$ disagreed and $5 \%$ strongly agreed with the use of ICT in the ESP course. In the ESP course, students are constantly using ICT technologies. They employed a variety of techniques to help students learn English.

Furthermore, ICT may be utilized not only for learning activities, such as joining a class meeting on Zoom, but also for interacting and communicating with people, such as utilizing Zoom to join a conference, job, and have a video meeting with their family during the Covid-19 epidemic. To summarize, the fifth indication reveals that virtually all students indicated that they frequently used ICT not only in the ESP Course but also for other necessary purposes.

Based on the findings above, it depicts the various responses from students at the Faculty of Mathematics and Science who use ICT in the ESP course, as measured by the percentage of all respondents' total scores. Students had a good attitude about the usage of ICT in the ESP course. This implies that the majority of students accept the usage of ICT throughout the ESP learning process.

\section{CONCLUSION}

ICT is defined as a form of technology used for creating, displaying, storing, manipulating and exchanging information to support English teaching and learning activities. ICT in ESP can supports students' learning success through promoting learning activity, enhance motivation, and improve learning achievement. However, although this research revealed that using ICT in ESP course were positive perceptions, it needs more to make rules to discipline and focus on lesson deeply. It is used for improve the ICT use in ESP teaching and learning process in order to enhance students' language skill that will they use for their future careers.

As ICT has important role for English teaching and learning activity, it is worth it to investigate other studies related to ICT use in ESP. This research focuses on identifying students' perceptions on using ICT in ESP course. It is suggested that future researchers conduct investigations on others issues related to ICT use and apply different research design.

\section{ACKNOWLEDGMENTS}

In the process of writing this research paper, the researcher realize that there are number of parties who have given supports until the paper is done. My deepest gratitude will be sent firstly to Allah SWT, the most merciful and the most compassionate. This research paper would have never completed without his blessing and mercies. Then, the researcher would like to express gratitude to my advisor, Prof. Dr. Yenni Rozimela, M.Ed., Ph.D for her thoughtful guidance, motivation, advice, and valuable feedback in the process of conduct a research. Finally, the researcher would like to thanks to students at the Faculty of Mathematics and Science of Universitas Negeri Padang who participate in this research.

\section{REFERENCES}

[1] Meleisea, E. (2007). The UNESCO ICT in education program. Bangkok, Thailand: United Nations, Education, Scientific and Cultural Organization.

[2] Wekke, Ismail \& Hamid, Sanusi. (2013). Technology on Language Teaching and Learning. A Research on Indonesian Pesantren. Procedia Social and Behavioral Sciences. 83. 585-589. 10.1016/j.sbspro.2013.06.111. 
[3] Hashmi ZF, Dahar MA, Sharif A. (2019). Role of Information and Communication Technology in Motivating University Undergraduate Students towards a Learning Task in Public Sector Universities of Rawalpindi City. social Criminol 7: 196. doi:10.35248/2375-4435.19.7.196

[4] Gordon, Tatiana. (2007). Teaching Young Children A Second Language. Connecticut : Praeger Publisher

[5] Dashtestani, R. \& Stojković, N. (2015). The use of technology in English for specific purposes (ESP) instruction: A literature review. The Journal of

Teaching English for Specific and Academic Purposes, 3(3), 435-456. Retrieved July 20, 2018 from

http://espeap.junis.ni.ac.rs/index.php/espeap/article /view/304/199

[6] Djamal, Merlin. (2018). Implementation of Blanded Learning Model based on Edmodo Application to Improve English for Specific Purpose (ESP) Learner's Interest at STIE Muhammadiyah Tanjung Redeb Kaltim. Jurnal Bahasa Lingua Scientia. 10. 10.21274/1s.2018.10.2.313-328.

[7] Laili, R. N., \& Nashir, M. (2020). The Use of Zoom Meeting for Distance Learning in Teaching English to Nursing Students during Covid-19 Pandemic. UHAMKA International Conference on ELT and CALL (UICELL). https://journal.uhamka.ac.id/index.php/uicell/articl e/view/6290/2138

[8] Alizadeh I. (2018). Medical Students' Perception of Using Electronic Learning Tools in an ESP program. IJREE Vol. 3 No. 1.

[9] Asmali, Mehmet. (2018). Integrating Technology Into Esp Classes: Use Of Student Response System In English For Specific Purposes Instruction. 18. 86-104.

[10] Motteram, G. (2013). Innovation in Learning Technology for English Language Teaching (Innovations Series). British Council. https://www.teachingenglish.org.uk/sites/teacheng/ files/C607\%20Information\%20and\%20Communic ation WEB\%20ONLY FINAL.pdf

[11] Widyaningrum, A. (2018). Strengthening ESP in Education 4.0. $2^{\text {nd }}$ English Language and Literature. International Conference (ELLiC) Proceedings - (ELLiC Proceedings Vol. 2, 2018)

[12] Arnó-Macià, E. (2012). The Role of Technology in Teaching Languages for Specific Purposes Courses. The Modern Language Journal, 96, 89104. Retrieved June 18, 2021, from http://www.jstor.org/stable/41478793

[13] Zivkovic, Sladana. (2016). The ESP TechnologySupported Learning Environment. European Journal of Social Sciences Education and Research. Vol 3 issues 2

[14] Keshtiarast, B \& Salehi, H. (2020). Investigating employing information communication technology for ESP learning: A case of Iranian EFL students' attitudes. International Online Journal of Education and Teaching (IOJET), 7(2), 412-433. http://iojet.org/index.php/IOJET/article/view/434

[15] Olaore, I. B. (2014). The impacts (positive and negative) of ICT on education in Nigeria. Developing Country Studies, 4(23), 154-156

[16] Yunus, Melor \& Nordin, Norazah \& Salehi, Hadi \& Embi, Mohamed \& Salehi, Zeinab. (2013). The Use of Information and Communication Technology (ICT) in Teaching ESL Writing Skills. English Language Teaching. 6. 10.5539/elt.v6n7p1.

[17] Ammanni, S., \& Aparanjani, U. (2016). The role of ICT in English language teaching and learning. International Journal of Scientific and Engineering Research, 7(7), 1-7.

[18] Buabeng-Andoh, Charles. (2012). Factors influencing teachers' adoption and integration of information and communication technology into teaching: A review of the literature. International Journal of Education and Development Using Information and Communication Technology (IJEDICT). 8. 136-155.

[19] Gay, L., Mills, G. \& Airasian, P. (2006) Educational Research Competencies For Analysis And Applications. 8th Ed. New Jersey, Pearson.

[20] Arikunto, S. 2010. Prosedur Penelitian Suatu Pendekatan Praktik. Jakarta: Rineka Cipta.

[21] Rahayu, F., S., Budiyamto, S., and Palyama. D. (2017). Analisis Penerimaan e-Learning Menggunakan Technology Acceptance Model (TAM) (Studi Kasus: Universitas Atma Jaya Yogyakarta). JUTEI Edisi Volume. 1 No. 2

[22] Vitoria, L., Mislinawati, M., and Nurmasyitah, N. (2018). Students' perceptions on the implementation of e-learning: Helpful or unhelpful?. Journal of Physics: Conference Series, 1088(), 012058-. doi:10.1088/17426596/1088/1/012058

[23] Hariadi, Isabella \& Simanjuntak, Debora. (2020). Exploring the Experience f EFL Students Engaged In Asynchronous E-Learning. Academic Journal Perspective : Education, Language, and Literature. 8. 72. 10.33603/perspective.v8i2.4194.

[24] Cakrawati, L.M. (2017). Students' Perceptions On the Use of Online Learning Platforms In EFL Classroom. English Language Teaching and Technology Journal (ELT-Tech Journal). 1(1). 2230.

[25] Basri, M \& Paramma, M. (2019). EFL Students' Perspective on the Usefulness of ICT based Learning in Indonesian Higher Education. 6. 105120. 10.26858/eltww.v6i2.10515.

[26] Wiyaka., Mujiyanto, J., and Rukmini, D. (2018). Students' Perception on the Usefulness of ICT-Based Language Program. English Language Teaching, 11(2), 53-. doi:10.5539/elt.v11n2p53 